\title{
An Overview on Ebola
}

\author{
Nooshin Bagherani ${ }^{1}$, Bruce R Smoller ${ }^{2,3 *}$, Ajith Prasanna Kannangara ${ }^{4}$, Serena Gianfaldoni ${ }^{5}$ Xingang Wang ${ }^{6}$ and Andy Goren ${ }^{6,7}$ \\ ${ }^{1}$ Dr. Nooshin Bagheran's office, Khuzestan Province, Iran \\ ${ }^{2}$ Department of Pathology, University of Rochester, School of Medicine and Dentistry, USA \\ ${ }^{3}$ Department of Dermatology, University of Rochester, School of Medicine and Dentistry, USA \\ ${ }^{4}$ Ministry of Health, Sri Lanka \\ ${ }^{5}$ Department of Dermatology, University of Pisa, Italy \\ ${ }^{6}$ Applied Biology, Inc. USA \\ ${ }^{7}$ Department of Dermatology, University of Rome (“G.Marconi”), Italy
}

\begin{abstract}
Ebola Hemorrhagic Fever (EHF) is a rare viral disease, caused by infection with Ebola virus. It is characterized by abrupt onset of fever, chills, malaise, gastrointestinal, respiratory, cutaneous, and central nervous system manifestations. In 2014, the World Health Organization (WHO) declared the outbreak of EHF to be a Public Health Emergency of International Concern. Up to now, no specific therapeutics or vaccines have been approved for this lethal disease.

Herein, we have reviewed EHF in terms of virology, immunology, epidemiological profile, transmission, clinical and para-clinical manifestations, prevention and, treatment with focus on dermatological points.
\end{abstract}

\section{Introduction}

The term of "viral hemorrhagic fever" was originated in the 1930s by Soviet investigators [1,2]. It includes diseases caused by 23 enveloped RNA viruses from 4 taxonomic families including Arenaviridae, Bunyaviridae, Filoviridae and Flaviviridae [1-3].

Ebola hemorrhagic fever (EHF) is a rare zoonotic disease, caused by infection with Ebola virus [4-9], belonging to the family Filoviridae [7-13] in the order of Mononegavirales [13,14]. The Filoviridae are composed of three genera, so-called Ebola virus, Marburg virus [11,1521], and Cuevavirus [22,23]. The Ebola virus and Marburg virus can cause fulminant hemorrhagic feversin humans [9,13,16,18,19,24-26] and nonhuman primates $[6,9]$.

The Ebola virus is an enveloped filament-shaped, non-segmented [27], negative-stranded RNA virus [8,12,14,27-28]. So far, 5 species of this virus have been identified, among which Zaire Ebola virus (ZEBOV) has the highest case-fatality rate $[20,29]$ and is responsible for the current outbreak of EHF [4,10,29-32]. In 1976, this subtype was first discovered near the Ebola River in Zaire (now the Democratic Republic of the Congo) $[4,9,10,29,33]$. The other species include Sudan Ebola virus (SUDV), Tai Forest Ebola virus (TAFV), Reston Ebola virus (RESTV), and Bundibugyo Ebola virus (BDBV) [5,10,11,15,29,31]. Among them, the RESTV is only pathogenic for nonhuman primates $[9,10,15-17,25,29,31,33]$. This latter was first identified in cynomolgus macaques (Macaca fascicularis) afflicted by fatal hemorrhagic fever in Reston, Virgina, in 1989 [14,17].

EHF is an acute viral syndrome [9], characterized by abrupt onset of fever [25,31,34-36], chills, malaise [34,35], fatigue, severe headache, myalgia, gastrointestinal distress $[25,31,35,36]$, maculopapular rash $[25,34,35]$, respiratory and central nervous system involvement [25], host immunosuppression [36,37], high viremia [37], disseminated intravascular coagulation [38], hypotension [35], and multiorgan failure resembling septic shock [35-38]. Most of patients develop hemorrhagic manifestations $[9,25,31]$ such as petechiae $[25,34,35]$, ecchymoses, mucosal haemorrhages, and uncontrolled bleeding at venipuncture sites $[34,35]$. These clinical presentations begin 2-21 days after exposure to virus [29,34].

Because of the high virulence $[7,39]$ and fatality rate $[6,7,14,21]$, the risk of human-to-human transmission [2,6,7], and the lack of an effective vaccine or treatment $[6,7,14,21]$, the Ebola virus is classified as biosafety level 4 and category A pathogen $[6,9,14,39]$.

In this study, we have reviewed the EHF in terms of virology, immunology, epidemiological profile, transmission, clinical and para-clinical manifestations, prevention and treatment with focus on dermatological points.

\section{Virology and immunology}

The genome of Ebola virus is 18,959 nucleotides in length, containing only seven Open Reading Frames (ORFs). Despite limited encoding capacity, this virus expands its gene functions by forming more proteins and assigning more functions to each of them. Nine proteins have been known to be translated, including nucleoprotein (NP), the polymerase cofactor viral protein (eVP35), the major matric protein (eVP40), glycoprotein (GP), soluble glycoprotein (sGP), small soluble glycoprotein (ssGP), transcription activator (eVP30),

Correspondence to: Bruce R Smoller, Professor and Chair, Department of Pathology, Professor, Department of Dermatology, University of Rochester, School of Medicine and Dentistry, USA; E-mail: bsmoller@me.com

Received: January 12, 2015; Accepted: January 24, 2015; Published: January 27, 2015 
the minor matrix protein (eVP24), and viral RNA-dependent RNA polymerase (L). The GP, a surface protein inserted into the viral membrane, functions during virus entry into the host cells by binding to its receptor and fusion with cell membrane [40].

In infected cells, the Ebola virus initiates genome replication and transcription with its own proteins. A positive-sense intermediate RNA is produced from the Ebola virus negative-sense RNA by the NP, eVP35 and L to serve as a temple for the generation of new genomes. For transcription, the mRNA is directly transcribed from the negativestrand genome with the aid of NP, eVP35, eVP30 and L [41].

The assembly of viral nucleocapsid with the NP and viral genome requires the eVP24 [42]. Silencing this by interfering with the RNA prevents the release of Ebola virus [43]. The nucleocapside is associated with a few eVP40, which is then transported onto the plasma membrane, where it is enveloped with the membrane-associated eVP40. Subsequently, the GP is transported to the plasma membrane where the viral particles finally form and bud [44].

The most abundant matrix eVP40, together with the eVP24, underlies the viral lipid envelope while bridging the nucleocapsid and membrane. The eVP40 has multiple conformations, ranging from monomers, to dimers, hexamers and RNA-bound octamers [45]. It is sufficient to form virus-like particles (VLPs) that resemble authentic Ebolavirus virions when are expressed in mammalian cells [46].

\section{Entry into the cell}

The Ebola virus entry into host cells is mediated by the membrane glycoprotein GP on the viral surface, which binds to the host cell membrane receptor T-cell Ig and mucin domain 1 (TIM-1). Ectopic expression of the TIM-1 in poorly permissive cells enhances the Ebola virus infection by 10 to 30 folds, while knockdown of the TIM-1 expression by the RNAi decreases infection of highly permissive cells [47].

The GP consists of two subunits including GP1, the receptorbinding subunit, and GP2, the membrane fusion subunit [48]. An intracellular receptor Niemann-Pick C1 (NPC1), a lysosomal cholesterol transporter, is also critical for the Ebola virus entry [49]. The GP1 binds to the NPC-1 directly within lysosomes, which promotes a late step in the entry proximal to the viral escape into the host cytoplasm [50].

The GP2 directly binds to and inhibits the tetherin, a cellular antiviral factor that restricts budding of structurally diverse enveloped viruses [51,52]. Tetherin is a type II trans-membrane glycoprotein that accumulates at the perinuclear compartment and at the plasma membrane when induced by interferon- alpha (IFN- $\alpha$ ). It functions in retention of the matured viral particles from release followed by internalization into the endosomal compartment [53]. The tetherin restricts budding of the Ebola virus-like particles that are produced by the eVP40 alone in the mammalian cells [52], while as this restriction is counteracted by the GP2 [52].

\section{Fighting with the immune system}

The Ebola virus causes high death rate in a few weeks by suppressing innate and adaptive immune system to facilitate its own replication. The macrophages and dendritic cells are the direct targets of the Ebola virus, and the natural killer cells and T lymphocytes are not infected but undergo apoptosis [54]. The macrophages represent the innate immune system, and its main function is to clear foreign pathogens, as well to secret key cytokines to signal the other immune cells. Infection of the macrophages triggers the formation of blood clots, release of the inflammatory proteins and nitric oxide, which leads to blood leakage through damaging the lining of the blood vessels [10].

Infection of the dendritic cells by the Ebola virus causes dysregulation of type I interferons (IFNs), cytokines that promote the virus clearance and apoptosis of the infected cells. These cells have not only innate immune function, but also serve as adaptive immune cells to present antigen to the naïve $\mathrm{T}$ cells for recognition. The Ebola virus inhibits the dendritic cell maturation and cytokine production without affecting its own replication, thus affecting the $\mathrm{T}$ cell activation $[55,56]$.

The Ebola virus directly inhibits the IFN signaling by binding its protein eVP24 to karyopherin alpha 5 (KPNA5) with high affinity, thus to compete with and inhibit tyrosine-phosphorylated STAT1 (PYSTAT1) nuclear transport [57]. The PY-STAT1 enters the nucleus to activate the IFN-stimulated genes against the virus by binding to the IFN-stimulated response elements or IFN-y-activated site elements.

The second protein that the Ebola virus utilizes to suppress the IFN expression is the eVP35, a double-stranded RNA (dsRNA) binding protein. The expression of IFN- $\alpha / \beta$ gene is induced by retinoic acid inducible gene I (RIG-I) [58]. The eVP35 inhibits the activation of RIG-I by directly binding to the PKR activator (PACT), preventing it from binding to and activating the RIG-I [59].

The eVP35 plays multiple other functions in addition to the IFN suppression. The inhibition of dendritic cell maturation by the Ebola virus is mediated by the eVP35 with its N-terminal but not the dsRNAbinding domain [60]. In immature dendritic cells of mice, expression of the eVP35 prevents the virus-stimulated expression of CD40, CD80, CD86 and major histocompatibility complex class II, as well as cytokines such as interleukin (IL)-6, IL-2 and tumor necrosis factor $a$ (TNF- $\alpha$ ), in addition to the IFN- $\alpha / \beta[60,61]$.

The ability of the Ebola virus to escape from the innate immune detection also depends on the dsRNA-binding properties of eVP35. Host usually detects the dsRNA from the virus genome or metabolite with the pattern recognition receptors (PRRs) such as RIG-I, MDA5, LGP2 and TLR-3, which then activates the IFN signaling cascade. However, the eVP35 coats the backbone of dsRNA and shields it from being recognized by the host PRRs [62]. Proliferation of the Ebola virus in the mammalian cells is further enhanced by the suppression of RNA silencing machinery by the eVP35 [63]. The silencing of the microRNA or RNA interference protects the RNA of Ebola virus from degradation, and thus favoring its translation and proliferation.

\section{Immune variation}

The individual variations in the immune response to Ebola virus are not well characterized, but rapid accumulation of genetic variations have been found interhost and intrahost after sequencing the genomes of Ebola virus from 78 patients in Sierra Leone [64].

\section{Epidemiology}

The Ebola virus has significant epidemic potential. There is limited information regarding its origin [5]. Systematically collecting clinical data during outbreaks of the EHF is necessary for understanding its clinical manifestations and introducing treatment strategies $[29,65]$.

The first recognized outbreak of Marburg virus hemorrhagic fever was reported in Germany and Yugoslavia in 1967 [14,16,25,36]. In 1976, the first and second outbreaks of EHF occurred in southern Sudan [10,66-70] from June to November [12], and in northern Zaire 
$[12,14,25,31,32,34,36,37]$ in September and October [12], which were caused by two distinct species of virus, the SUDV and ZEBOV, respectively [14]; these resulted in 284 cases with 53\% mortality, and 318 cases with $88 \%$ mortality, respectively $[12,34]$.

Between 1979 and 1994, no outbreak of the EHF was reported globally, followed by near simultaneous reemergence of the disease in Gabon, Cote D'Ivoire, and the Democratic Republic of the Congo [14,71]. About 21 outbreaks of this infective disease have been reported in several sub-Saharan African countries. Among them, the largest one took place in the Gulu district of Uganda in2000-2001.The SUDV was responsible for this outbreak [31]. Between 1994 and 2002, four outbreaks of EHF in Gabon were reported [30]. Since 2007, six outbreaks of this viral lethal disease occurred in Uganda [71]. In one of them in 2007 and 2008, the (BDBV) was responsible [15,72] with a case fatality rate of about $25 \%$ [11].

Polonsky et al. suggested the causes of this change in epidemiological profile might include changes to the surveillance system, changes in patterns of interaction between humans and bats, and changes in the filoviral sero prevalence in the host species [71].

On August, 2014, the World Health Organization (WHO) declared the outbreak of EHF to be a Public Health Emergency of International Concern $[4,29,72,73]$. This ongoing outbreak commenced in Guinea $[29,32,72]$ in December 2013and spread to other countries [32,72]. Most cases of this viral disease have been seen in Guinea, Liberia, and Sierra Leone $[4,10,32,74,75]$. Cases of this disease have also been reported in the Democratic Republic of the Congo [4], Nigeria [10,7], Senegal $[4,10]$, the United States of America [4,10,76,77], Canada, and Benin [76]. To stop this current spread, in response to the severity of the situation, for the first time, the WHO agreed to the use of experimental treatment against this lethal infection [73].

The 2014 outbreak is the largest $[4,32,72,75]$, longest and most widespread outbreak of this viral disease that has been reported [32]. The nearest deadly outbreaks of EHF to this recent one occurred in the Democratic Republic of the Congo and Uganda in August and November 2012, respectively [61].

The WHO has drawn up a list of 15 countries at risk for outbreak of EHF including in Mali, Ivory Coast, Senegal, Guinea-Bissau, Benin, Cameroon, the Central African Republic, the Democratic Republic of Congo, Ghana, South Sudan, Nigeria, Mauritania, Togo, and Burkina Faso [74]. It has been estimated that 22 million people living in areas of Central and West Africa are at risk of acquiring this disease [29].

EHF is a highly lethal disease [14,71]. Its mortality rate has been reported to be between 50 [10,12,76,78]- $90 \%$ $[5,6,11,12,17,18,20,21,27,29-31,33,36,37,39,61,76,79,80]$ in humans and up to $100 \%$ in nonhuman primates [61], depending on virus species $[17,39]$. In comparison with most previous outbreaks, the case fatality rate for the 2014 outbreak in West Africa has been reported to be much lower. Till October 2014, more than 8399 cases with 4033 deaths was reported [4], with the naïve case fertility rate of 51\% [81].

\section{Transmission}

Many studies have suggested that hammer-headed fruit bats (Hypsignathus monstrosus) [4,10,14,32], little collared bats (Myonycteris torquata) belonging to the family Pteropodidae [10,14,32,71], androdents [14] are reservoirs of this virus. It appears that humans may be infected by direct exposure to these reservoirs or intermediate hosts, especially non-human primates (e.g. gorillas, monkeys) [7]. In the past, exposure to and eating of freshly- killed bats have led to EHF [82]. Direct human-human transmission is also possible and usually represents the first modality by which epidemics take off. This mode of transmission comes from direct contact with blood or other bodily fluids of an infected patient during the acute phase of the disease [7].

Ebola virus has been detected in the saliva, breast milk, stool and tears [7]. The infectious virus particles or Ebolaviral RNA have been identified in semen, genital secretions, as well as in the skin of affected patients [14]. This virus in saliva may be transmitted with intimate contact and sharing food [7]. Moreover, it is transmitted to humans through abrasions in the skin, exposure of their mucosal surfaces, or by parenteral route with blood and bodily fluids from another infected individual $[10,14,83,84]$. The presence of the pathogen in breast milk is important for the mother-to- breastfed child transmission. Finally, the viruses in semen and tears may spread with direct and indirect contact. The virus seems not to be present in urine, vomit or sweat. Hence, the risk of transmission via the contact with the skin of an infected man is low [7].

The contact with contaminated surface and fomites has been suggested as a way for infection transmission. The role of airborne viral transmission is uncertain. Although the virus transmission through air or water seems not to be possible, recently airborne transmission of EHF has been described in animals and in controlled laboratory conditions [7]. Direct contact with the infected patients or cadavers seems to be the cause for the most of human outbreaks [14].

\section{Laboratory investigation}

Ebola virus infection can be diagnosed during acute phase through the following assays:

A) Virus isolation using Vero or Vero E6 cell lines $[8,10]$

B) Reverse transcriptase polymerase chain reaction(RT-PCR) $[9,10,14,85]$ and real time quantitative PCR assays $[10,22]$

C) Antigen- capture enzyme- linked immunoabsorbent assay (antigen-capture ELISA) $[9,10,14,22]$

D) IgM ELISA [8-10,14]

In the later phase, the following tests are used for diagnosing this infection:

A) IgM and IgG ELISA [8-10,14,35,85]

B) Immunostaining techniques for detection of the viral antigens [10]

C) Immunohistochemical tests for detecting the Ebola virus antigens [8-10]

D) In-situ hybridization techniques for detecting the viral RNA $[10,38]$

For quantitative assays, a cell-based plaque assay and an end-point titration assay (TCID50) have been developed [3,10].

Summarily, the laboratory findings in patients with the EHF include:

1- Leukopenia [5,10,14,19,24,39,86,87]: Increased lymphoid cell apoptosis due to release of TNF-a leads to leukopenia $[10,19]$. This early leukopenia is associated with lymphopenia, subsequent neutrophilia, and left shift with atypical lymphocytes [14]. Lymphopenia is a marker of poor prognosis 
in this disease [10].

2- Thrombocytopenia $[3,10,14,25,39,87]$

3- Decreased hemoglobin and hematocrit [3]

4- Increased levels of the aminotransferases [5,10,14,37,39]: Significant elevation of serum aspartate and alanine aminotransferase levels is a hallmark of the EHF in humans [37].

5- Changes in the biomarkers of coagulopathy $[10,19,25,31,34,38,39,88]$ : Increased levels of the thrombin, partial thromboplastin and fibrin split products are reported in the EHF due to the occurrence of disseminated intravascular coagulation $[3,10,14,31,39]$. Studies have shown that the serum tissue plasminogen activator, D-dimer, thrombomodulin, and, tissue factor levels are increased in the disease course [31].

6- Increased levels of the inflammatory and pro-inflammatory mediators $[2,3,10,24,34,38,86]$ : In this viral infection, elevated levels of the inflammatory and pro-inflammatory mediators including the IL- 6, IL-8, IL-10 [5,31], IL-15, IL-18 [5], macrophage inflammatory protein $1 \beta[5,32]$, IFNs, monocyte chemo-attractant protein 1 , TNF- $\alpha$, macrophage colony stimulating factor, and reactive oxygen species have been reported $[5,6]$. Increased levels of the cytokines lead to the shock and multi-organ failure during terminal phase of the disease [10,32], and are associated with fatal outcomes [31].

7- Elevation of the blood urea nitrogen, and creatinine levels $[5,31,39]$

8- Decreased levels of the serum calcium [31,39], sodium, and potassium [39]

9- Increased the $\mathrm{C}$ reactive protein [31]

10- Hypergammaglobulinemia [31]

11- Hyperferritinemia [31]

12- Hypoalbuminemia [5,31]

13- Proteinuria [14]

The acute phase response is a constellation of the host responses following the infection, which is triggered by the proinflammatory cytokines. Increased CRP and serum amyloid antigen, hypoalbuminemia, hypergammaglobulinemia, and hyperferritinemia are markers of this response, used clinically in the disease process to help in diagnosis and to follow a patient's response to the therapy [31].

The most important para-clinical findings in the course of EHF have been summarized in Table 1 .

\section{Histopathology}

Pathologic findings occurring within the skin of patients infected with the Ebola virus are difficult to enumerate [68]. This stems in large part from the fact that autopsies are rarely performed on these patients and are, in fact, discouraged by governmental regulatory agencies $[8,89]$. The EHF can be transmitted to humans during autopsies. Further, in most patients, the majority of changes occur within the liver [90].

At autopsy, patients frequently demonstrate large areas of ecchymosis on the skin and mucosal surfaces. The histologic changes are relatively mild, consisting primarily of papillary dermal edema and dermal hemorrhage. Endothelial cell swelling and necrosis are present in varying degrees, mimicking the changes found to a pronounced degree in the liver. Fibrin thrombi and vascular necrosis have not been identified in skin examined from these patients. There is no significant inflammatory infiltrate described in most cases. This has been attributed to significant immune dysregulation caused by the virus $[8,68]$. Actual depletion of T cells and NK cells has been demonstrated in splenic tissue of affected patients. In animal models, vasculitis has been described as part of a multi-system disease that is present in lungs, spleen, liver, adrenal glands and kidneys. In this same study, fibrin thrombi were observed in vessels throughout the dermis [5].

Use of immunohistochemistry reveals the presence of viral antigens concentrated in the epidermal dendritic cells, endothelial cells and fibroblasts $[5,8]$. While organisms are not readily apparent in the skin suing routine histologic stains, eosinophilic globules representing aggregates of nucleocapsids have been described in infected hepatocytes [16]. To a lesser degree, the eccrine and sebaceous glands may demonstrate viruses. Viral organisms are readily apparent within this population of cells on electron microscopic examination [8].

\section{Clinical manifestation}

\section{Incubation period and duration of the disease course}

The incubation period of EHF varies between 2-21 days with an average of $4-10$ days $[9,10,14,20,29,32,34,73,84]$. The outcome of the disease in terms of death or recovery is usually observed during 5 to 15 days of illness $[32,73]$. Patients who survive infection begin to show a decrease in amounts of the circulating virus and clinical improvement around days of 7 to 10 . Most deaths occurred between days 7 and 12 of illness [91].

\section{Initial signs and symptoms}

Clinical data and other information from various sources have shown that patients with EHF become ill abruptly with a variety of nonspecific signs and symptoms, including fever (73\%),severe headache (95\%), arthralgia, myalgia (76\%), and general malaise (86\%), sometimes accompanied by chills which are often confused with malaria or dengue in the tropical climates $[14,16,29,73,84]$.

\section{Subsequent signs and symptoms}

This initial period is followed by a period where in the patients

Table 1. Most important paraclinical findings in the course of EHF.

\begin{tabular}{|l|l|}
\hline Hemoglobin \& Hematocrit & Progressive decline (with hemorrhage) \\
\hline White blood cells & Early leukopenia with lymphopenia and subsequent neutrophilia, left shift with atypical lymphocytes, in fatal cases leukocytosis \\
\hline Platelets & Thrombocytopenia \\
\hline Liver-associated enzymes & Highly raised serum aminotransferases (aspartate aminotransferase typically exceeding alanine aminotransferase), hyperproteinaemia \\
\hline Renal functions & Hematuria, proteinuria \\
\hline & Prolongation of prothrombin and partial thromboplastin time and fibrin split products are detectable \\
\hline Other serum chemistry values & Serum amylase concentration may be raised \\
\hline
\end{tabular}


show flu-like symptoms accompanied by the following manifestations:

(a) Gastro-intestinal manifestations: dysphagia (71\%), abdominal pain $(60 \%)$, anorexia $(71 \%)$, nausea and vomiting $(73 \%)$, and diarrhea (73\%) $[9,14,84,91]$

(b) Respiratory manifestation: pharyngitis, chest pain, shortness of breath, non-productive cough (rare), and nasal discharge $[14,32,73,83,84,91]$

(c) Neurological manifestations: delirium (hypoactive \& hyperactive), confusion, slowed cognition, agitation, and seizures (less frequently) $[9,14,91]$

\section{Cutaneous manifestations}

Most documented literatures of EHF noted that the appearance of a rash early in the course of illness, usually around 5 to 7 days after onset of the disease is often considered as an important differential feature $[16,25,34,35]$. Around day 8, most patients show cutaneous erythema over the entire body, sometimes accompanied by cyanosis [89]. In a number of reported outbreaks, a cutaneous eruptionhas been seen in $25 \%-52 \%$ of individuals $[16,25,34,35]$. It is frequently described as being a non-pruritic, purplish-red, maculo-popular rash on the trunk and shoulders associated with varying severity of erythema or cutaneous flushing. Cutaneous eruptions which sometimes begins focally, and then become diffuse, generalized and confluent (centripetal) are described as morbilliform (measles-like) or scarletiform, that later is followed by desquamation. The rash may be difficult to discern in dark-skinned individuals [14,16,32]. Petichiae, ecchymoses and persistent bleeding from injection or venipuncture sites have been reported $[14,34,35,73]$.

\section{Mucosal manifestations}

Studies have shown that $30-80 \%$ of patients with EHF develop multiple foci of mucosal hemorrhage, mostly at the end of the illness. These are most evident in the conjunctiva $[14,34,35,73]$. In the eyes, mouth and pharynx, mucosal lesions are commonly seen, as is bilateral conjunctival congestion [92]. Post-mortem evidence of visceral hemorrhagic effusions has been described [14]. Massive bleeding is usually observed only in fatal cases when it is typically localized to the upper/lower gastrointestinal and respiratory tract as manifested by gingival bleeding, hematemesis, melena, epistaxis and hemoptysis $[1,25,31,35,36]$. Hematuria, postpartum vaginal bleeding and intracranial hemorrhage are among the other described bleeding manifestations in the course of EHF $[9,20,84]$.

\section{Non-cutaneous manifestation}

The other abnormalities on clinical examination that have been mentioned frequently in various case presentations or outbreak reports include pharyngeal erythema associated with sore throat, lymphadenopathy, and tender hepatomegaly $[9,16]$. Jaundice, as manifested by icteric sclera, is a rare occurrence and hiccups has been described as part of the end stage of theterminal syndrome $[16,83]$.

\section{Diagnosis and differential diagnosis}

The variable clinical presentations and the absence of relevant epidemiological history of EHF can make the differential diagnosis difficult. Early symptoms may resemble other tropical infectious diseases like influenza, malaria, typhoid fever, leptospirosis, relapsing fever, anthrax, typhus, murine, non typhoidal salmonellosis, Dengue fever, Chikungunya fever, yellow fever, Lassa fever, Marburg fever, fulminant viral hepatitis, meningococcal septicemia and various forms of encephalitis, which are also prevalent in these countries [14,20,32].

Confounding noninfectious syndromes with hemorrhage such as acute leukemia, lupus erythematous, idiopathic thrombocytopenic purpura, and hemolytic uremic syndrome also fall into the differential diagnosis [9].

The differential diagnoses of EHF have been summarized in the Table 2 .

\section{Prevention}

Because of the high risk of transmission, the poor prognosis and the lack of valid therapeutic options for EHF, prevention is pivotal. Education about EHF is the first step. People must be instructed about the infectious etiology, risk factors, routs of transmission, and clinical manifestations of the disease. People who live in geographical areas at high risk for EHF must practice careful hygiene to avoid contact with body fluids of infected humans and animals. Moreover, they have to limit the contact with bats and items which may have come in contact with known EHF patients [77].

Another group of people at high risk for EHF are healthcare workers. They must use appropriate personal protective equipment and proper sterilization measures. Each case of suspected infection must be hospitalized in an isolated ward in a proper medical center [77].

\section{Treatment}

Although considerable advances have already been made in preventing and treating viral infections, no specific therapeutics or vaccines have yet been approved for EHF [3-7,9,11,12,14,25$27,34,36,76,86,93]$. With the 2014 outbreak, for the first time, the WHO agreed to the use of experimental treatments against this lethal viral infection $[32,73,93,94]$.

Introduction of broad-spectrum treatments targeting common viral or host factors are most desirable [3]. More insights into the Ebola virus pathogenesis are required for developing vaccine and antiviral drugs [6]. On the other hand, as more treatment modalities are explored for the Ebola virus infection, additional cases of delayed death will be recognized, and consequently the pathogenesis of this highly fatal disease will be better explored [87].

Studies have shown that a relevant, transferable adaptive immune response occurs late in this infection [39]. Because this response occurs too late to combat the infection, it appears that therapeutic strategies that slow the disease progression to allow the developing adaptive immune response to respond are appropriate for treating this lethal disease $[14,24]$. Moreover, each stage in the viral entry process and viral replication enzymes can be a potential target for therapeutic strategies to interrupt the viral replication [34].

Patients undergoing experimental therapy hope to survive despite

Table 2. The differential diagnoses of the EHF.

\begin{tabular}{|l|l|}
\hline Category & Diseases \\
\hline Tropical viral diseases & $\begin{array}{l}\text { Influenza, dengue fever, chikungunya fever, yellow fever, } \\
\text { lassa fever, marburg fever, various forms of encephalitis }\end{array}$ \\
\hline Tropical bacterial diseases & $\begin{array}{l}\text { Malaria, typhoid fever, leptospirosis, relapsing fever, } \\
\text { anthrax, typhus, murine, non typhoidal salmonellosis, } \\
\text { meningococcal septicemia }\end{array}$ \\
\hline $\begin{array}{l}\text { Hematological and other } \\
\text { autoimmune diseases }\end{array}$ & $\begin{array}{l}\text { Acute leukemia, lupus erythematous, idiopathic } \\
\text { thrombocytopenic purpura, hemolytic uremic syndrome }\end{array}$ \\
\hline
\end{tabular}


the fact that the efficacy and adverse effects of these treatments are unknown [95].

The agents experimentally used in treatment and prevention of this lethal infection include:

1- Neutralizing monoclonal antibodies [25,32,34,37,38,96]: The efficacy of passively acquired antibodies in reduction of the viral burden during the Ebola virus infection has been shown [14]. MB003 [25] and ZMapp [25,32,33,93,96,97] are two separate monoclonal antibody cocktails that have demonstrated successful protection against this lethal infection. It appears these antibodies in combination with other pharmaceutical agents can be beneficial in managing this viral disease [14].

2- Anti-sense phosphorodiamidate morpholino oligomers [10,14,24,25,34,86] such as AVI-6002 and AVI-6003 [10,25]: Antiviral agents targeting viral genes based on antisense phosphorodiamidate morpholino oligomers are greatly effective in treating the Ebola virus infection by allowing the host extra time to act against the viral infection by slowing down the viral replication [24,25]. These agents have been approved for the phase I clinical trials by the food and drug administration in treatment of the Ebola virus infection [10,25].

3- Lipid nanoparticle small interfering RNA $[10,14,25,27,32,34,37,38,98]$ such as LNP-siRNA:TKM-Ebola [10]. The efficacy of these compounds has been shown in studies [10,24,27,37]. It appears that they act by allowing the host extra time to combat the viral infection by slowing down the viral replication [24]. Theses antiviral agents have been approved for phase I clinical trials by the food and drug administration for treating EHF [10]. Studies have demonstrated that small interfering RNAs are more efficacious than anti-sense phosphorodiamidate morpholino oligomers in the treatment of Ebola virus infections [25].

4- Nucleoside analogues [10,25,96]: Studies have shown that BCX4430 [25,32], a broad spectrum nucleoside analogue, inhibits critical replicative processes in the virus life cycle through inhibiting viral RNA polymerase function and acting as a non-obligate RNA chain terminator [25]. The $S$-adenosylhomocysteine hydrolase inhibitors are adenosine analogues that have a protective effect against Ebola virus through inhibiting replication of the virus $[34,96]$.

5- Coagulation modulators [20,24,34,35,86]: Coagulation modulators have successfully been used in treating Ebola virus infection $[24,86]$. It appears that these therapeutic agents act via diminishing coagulopathy, viral titers, and inflammatory cytokines [24]. In this group of drugs, recombinant nematode anticoagulant protein $\mathrm{C} 2$ $[10,25,34,87]$ has been shown to act through blocking the factor VIIa/ tissue factor pathway of blood coagulation $[20,25,34,87]$. This agent has shown $33 \%$ efficacy in the treatment of ZEBO Vin non-human primates [14]. Furthermore, we can introduce recombinant human activated protein $C$ in this medicinal group $[10,14,19,25,87]$, which licensed for the treatment of severe sepsis in humans at high risk of death $[19,87]$. Although studies have strongly revealed that tissue factor expression or release from infected monocytes or macrophages is the key factor for the coagulopathy seen in the Ebola virus infection, multiple factors are responsible for this coagulation irregularities. Hence, it is likely that combination therapy with multiple coagulation-modulating agents can be the best approach for treating the Ebola virus infection [19].

6- Mannose-binding lectin therapy [86]: Circulating mannosebinding lectin is the first-line host defense against a wide range of pathogens. It preferentially recognizes glycosylated viruses such as the
Ebola virus, and Marburg virus, and mediates complement-dependent virus neutralization. Michelow et al., have shown the efficacy of high dose of recombinant human mannose-binding lectin in treating EHF. It appears as though this agent acts through increasing the B lymphocyte and CD11b1 granulocyte counts, down-regulating the intrahepatic pro-inflammatory mediators (IL-1b, andIL-17) and Th2 cytokines (IL5 , IL-10, and IL-13) early in the disease course, and inhibiting viral replication [86].

7- Fusion inhibitors [34]: Chemotherapeutic agents targeting the cathepsin L cleavage of the viral glycoprotein can subsequently inhibit fusion of the virus with the host cell membrane [10].

8- Budding inhibitors [34]: The Ebola virus budding is mediated by two motifs within the VP40. The efficacy of budding inhibitors in treating the Ebola virus infection needs to be more extensively studied [34].

9- Pyrazinecarboximide derivative T-705 (favipiravir) $[10,32,37,94]$ : For the first time, in 2002, it was introduced as an inhibitor of the influenza virus replication. It is converted by host enzymes to the T-705-ribofuranosyl-50-triphosphate, which acts as a nucleotide analogue. Favipiravir selectively inhibits the viral RNA-dependent RNA polymerase or causes lethal mutagenesis upon incorporation into the virus RNA. Oestereich et al., have shown efficacy of favipiravir for advanced the ZEBOV infection in an animal model. They revealed that this agent reduced viremia, ameliorated clinical and biochemical signs of disease, and prevented lethal outcome [37].

10- Agents targeting the Ebola virus VP35 and VP40 [10]: The data have shown the Ebola virus protein VP35 functions as a type I of IFN (IFN- $\alpha / \beta)$ antagonist. It appears that the type I IFN response is a critical determinant of the Ebola virus pathogenicity [32]. The VP40 is the most abundant protein found in the virions, which regulates budding and egress from the host plasma membrane [99].

11- Ion-channel inhibitors [27]: Amiodarone is on top of this cluster of drugs. It is a multi-ion channel inhibitor which is administered as an anti-arrhythmic agent. Gehring et al., have shown that amiodarone acts as a potent and specific inhibitor for filoviral cell entry. In this study, similar results have been seen with dronedarone and verapamil. The exact mechanism by which theses agents inhibit viral cell entry have not been known. It appears that amiodarone acts on the host cell rather than the incoming virus [27].

12- Estrogen receptor modulators [37,77]: Clomiphene, an estrogen receptor modulator, is effective in treating the EHF perturbing the role of Niemann-Pick C1 in viral entry [77].

13- Heme oxygenase-1 inducers [11]: Heme oxygenase-1 is an enzyme that catalyzes the rate-limiting step in heme degradation to carbon monoxide, biliverdin, and free iron. Studies have shown that heme oxygenase- 1 inducers such as cobalt protoporphyrin has antiinflammatory, anti-oxidant and anti-viral effects. They protect tissues and organs from numerous stresses, including septic shock, virusinduced oxidative injury, and hemorrhage-induced hypoxia. HillBatorski et al., showed that cobalt protoporphyrin administration, pre- and post-infection, significantly suppressed the Ebola virus transcription and replication via inducing the heme oxygenase-1 [11].

14- IFNs [20,34,37,70]: The Ebola virus can suppress early host immune responses by antagonizing IFN I responses. Studies have demonstrated that treatment with recombinant human adenovirus 
serotype 5 virus expressing consensus human IFN- $\alpha$ is beneficial in treating this infection [25].

15- Sicarius spider [100]: A remedy made from the sicarius spider may is effective in the treatment of EHF [100].

16- New compounds such as FGI-103, FGI-104, FGI-106, dUY11, and LJ-001[10]

Most of these drugs show protection when administered shortly after infection; they don't have a therapeutic benefit beyond the time window of 2 days post infection. Studies have recently shown that the combination of monoclonal antibodies with adenovirus-vectored IFN$\alpha$ has extended the treatment window to 3 days post-exposure [25,37].

Taken together, because there is no completely effective therapy for EHF, the primary control strategy is based on aggressive contact tracing and isolation of suspected cases in specialized isolation wards $[7,32]$.

To achieve better therapeutic response, supportive care of complications is admixed with these experimental therapeutic regimens in the clinical management of patients with EHF [4,9,35,95]. Particular attention should be paid to maintenance of hydration, circulatory volume $[9,35]$, electrolyte balance [14], and blood pressure and the provision of supplemental oxygen [9]. Organ failure should be managed appropriately $[14,32,35]$.

Patients presenting with hypotension and shock are difficult to manage because the administration of intravenous fluids can easily evolve into pulmonary edema. Management of bleeding is controversial; mild bleeding with no evidence of disseminated intravascular coagulation should not be treated. Disseminated intravascular coagulation should be treated prophylactically through the replacement of coagulation factors and platelets [9]. Antiemetics, antidiarrheal agents, and rehydration solution are aggressively administered to reduce massive gastrointestinal losses $[35,91]$. Analgesics, antipyretics, sedatives, and antipsychotics should be administered as needed [35].

To improve our understanding of the clinical course of this viral infection, regular recording of pulse, blood pressure, fluid intake, and urine output, together with careful record keeping is essential. These data are helpful to evaluate the benefit of such therapeutic approaches [16].

In cases of EHF, administration of aspirin, non-steroidal antiinflammatory drugs, anticoagulant therapies, and steroids are contraindicated [9]. To avoid trauma and risk of transmission, injections, catheterizations, and parenteral interventions must be minimized [9,35].

\section{Vaccination}

Although a variety of preventive and therapeutic vaccines have been introduced for EHF [10], no vaccine is currently licensed for application in humans [37]. In preventive vaccination, also termed active immunization, live-attenuated, killed or inactivated, and subunit vaccines are used [10]. Because of the potential of reversion, live-attenuated vaccines appears not to be appropriate for the Ebola virus [10,14]. However, live attenuated recombinant Ebola virus vaccine vectors have been developed based on the background of less virulent viral systems including vesicular stomatitis virus and human parainfluenza virus [14]. The efficacy of recombinant vaccines based on vesicular stomatitis virus has been shown in EHF including both prophylactic and post-exposure treatment situations [14,21]. These vaccines rapidly elicit potent host innate immune responses due to increased secretion of IFN I by the dendritic cells, as well as the specific $\mathrm{B}$ and $\mathrm{T}$ cell immune responses [25].

Regarding the sporadic nature of disease outbreaks and the ethical issues, early-stage development of vaccines has occurred in mouse and guinea pig models $[6,18,39]$. To consider that the Ebola virus in rodents does not reproduce the extensive disseminated intravascular coagulation seen in human cases, these models are not necessarily predictive of vaccine efficacy in humans. Non-human primates are the preferred animal model for the human Ebola virus infection because their immune system is similar to humans' [18]. They are the only animals that are lethally infected with this virus, and the resulting pathology in them is close to that seen in humans [39].

DNA-based $[42,101]$ and protein-based vaccines are safe but often lack the required immunogenicity for long-term protection against the Ebola virus [42]. The DNA vaccines require booster vaccinations to achieve greater protective immunity [101]. To accentuate the efficacy of protein-based vaccines, adjuvants are required. These latter agents are compounds that increase immunogenicity without causing deleterious, non-specific immune activation. Alum-based compounds, a formulated monophosphoryl lipid A and toll-like receptor agonists are used as adjuvants in human vaccines [42].

The Ebola virus-like particle vaccines, containing the viral matrix protein, VP40, and glycoprotein are highly efficacious against the Ebola and Marburg viral diseases [42].

Due to the infection over-spreading last September, a pharmaceutical company started an experimental study on a vaccine to prevent EHF in a group of adult humans [102].

Therapeutic vaccination, so-called passive immunization, [10] is administered in post-infections $[10,86]$. In this immunization, antibodies that are either produced in animals [10,14] or sera/ immunoglobulins from patients who have survived from infection are administered $[10,14,27]$. Studies have shown that therapeutic vaccine treatment in Ebola virus-infected non-human primates after infection provides partial protection in an antigen-specific manner [24].

\section{Prognosis}

Severe outcome of EHF is attributed to a combination of rapid uncontrolled viral replication, host immune suppression, and vascular dysfunction seen in the disease course. Studies have shown that the majority of organs, including the spleen, liver, blood, and lymph nodes are involved in process of this disease. Moreover, data collected from fatal human and nonhuman primate cases have shown that the Ebola virus infection triggers a strong inflammatory response that is responsible for disease progression [6]. Massive intravascular apoptosis, and impaired humoral responses related to absent specific IgG and barely detectable IgM are associated with fatal outcome in this infection [85]

In the course of EHF, high levels of viremia are associated with poor prognosis [31]. In this disease, activation of the pro-inflammatory cytokines and chemokines including IFNs, ILs, monocyte chemoattractant protein 1, TNF- $\alpha$, and reactive oxygen species results in dysregulation of the immune, vascular, and coagulation systems, creating multiple organ failure and shock [6]. These findings are associated with fatal outcomes [6,31]. Moreover, there is relationship between the serum aminotransferase, ferritin, thrombomodulin, tissue plasminogen activator, D-dimer, nitric oxide, macrophage-colony 
stimulating factor, monocyte chemo-attractant protein 1, blood urea nitrogen, creatinine, and albumin levels with the fatal outcomes [31].

Particularly vulnerable patient populations include children less than 5 years of age, old individuals, and pregnant women. Women in the late second- or third-trimester have an increased risk of miscarriage $[14,91]$.

Studies have demonstrated that human leukocyte antigen B67 (HLA-B67), HLA-B15, and marked CD8 lymphopenia are associated with fatal outcome, and HLA-B7 and HLA-B14 are associated with non-fatal outcome [31].

In the absence of specifically-approved treatments, the management of EHF is largely limited to supportive care and experimental therapeutic regimens [27]. Considering the critical role of inflammatory responses in the disease progression, it appears that an early controlling of these responses can lead to recovery [6].

In resource-poor settings, its mortality is high, and even in the best caring situation, treatment is a great challenge [27]. Although this infection does not necessarily end in death, the fatality rate is high, because a reliable and successful treatment or immunization has not yet been introduced [100]. Patients who survive typically start to improve between 6 to 11 days after onset of symptoms [92].

\section{References}

1. Paessler S, Walker DH (2013) Pathogenesis of the viral hemorrhagic fevers. Annu Rev Pathol 8: 411-440. [Crossref]

2. Schnittler HJ, Feldmann H (2003) Viral hemorrhagic fever--a vascular disease? Thromb Haemost 89: 967-972. [Crossref]

3. Johnson RF, Dodd LE, Yellayi S, Gu W, Cann JA, et al. (2011) Simian hemorrhagic fever virus infection of rhesus macaques as a model of viral hemorrhagic fever: clinical characterization and risk factors for severe disease. Virology 421: 129-140. [Crossref]

4. Peacock G, Uyeki TM, Rasmussen SA (2014) Ebola virus disease and children: what pediatric health care professionals need to know. JAMA Pediatr 168: 1087-1088. [Crossref]

5. Twenhafel NA, Mattix ME, Johnson JC, Robinson CG, Pratt WD, et al. (2013) Pathology of experimental aerosol Zaire ebolavirus infection in rhesus macaques. Vet Pathol 50: 514-529. [Crossref]

6. Cilloniz C, Ebihara H, Ni C, Neumann G, Korth MJ, Kelly SM, et al. (2011) Functional genomics reveals the induction of inflammatory response and metalloproteinase gene expression during lethal Ebola virus infection. J Virol 85: 9060-9068. [Crossref]

7. Bausch DG, Towner JS, Dowell SF, Kaducu F, Lukwiya M, et al. (2007) Assessment of the risk of Ebola virus transmission from bodily fluids and fomites. J Infect Dis 196 Suppl 2: S142-147. [Crossref]

8. Zaki SR, Shieh WJ, Greer PW, Goldsmith CS, Ferebee T, et al. (1999) A novel immunohistochemical assay for the detection of Ebola virus in skin: implications for diagnosis, spread, and surveillance of Ebola hemorrhagic fever. Commission de Lutte contre les Epidémies à Kikwit. J Infect Dis 179: S36-47. [Crossref]

9. Casillas AM, Nyamathi AM, Sosa A, Wilder CL, Sands H (2003) A current review of Ebola virus: pathogenesis, clinical presentation, and diagnostic assessment. Biol Res Nurs 4: 268-275. [Crossref]

10. Ansari AA (2014) Clinical features and pathobiology of Ebolavirus infection. $J$ Autoimmun 55: 1-9. [Crossref]

11. Hill-Batorski L, Halfmann P, Neumann G, Kawaoka Y (2013) The cytoprotective enzyme heme oxygenase-1 suppresses Ebola virus replication. $J$ Virol 87: 1379513802. [Crossref]

12. Gonzalez JP, Herbreteau V, Morvan J, Leroy EM (2005) Ebola virus circulation in Africa: a balance between clinical expression and epidemiological silence. Bull Soc Pathol Exot 98: 210-217. [Crossref]

13. Geisbert TW, Jahrling PB (1995) Differentiation of filoviruses by electron microscopy. Virus Res 39: 129-150. [Crossref]
14. Feldmann H, Geisbert TW (2011) Ebola haemorrhagic fever. Lancet 377: 849-862. [Crossref]

15. Lennemann NJ, Rhein BA, Ndungo E, Chandran K, Qiu X, et al. (2014) Comprehensive functional analysis of N-linked glycans on Ebola virus GP1. MBio 5: e00862-00813. [Crossref]

16. Kortepeter MG, Bausch DG, Bray M (2011) Basic clinical and laboratory features of filoviral hemorrhagic fever. J Infect Dis 204 Suppl 3: S810-816. [Crossref]

17. Marsh GA, Haining J, Robinson R, Foord A, Yamada M, et al. (2011) Ebola Reston virus infection of pigs: clinical significance and transmission potential. J Infect Dis 204 Suppl 3: S804-809. [Crossref]

18. Carrion R Jr, Ro Y, Hoosien K, Ticer A, Brasky K, et al. (2011) A small nonhuman primate model for filovirus-induced disease. Virology 420: 117-124. [Crossref]

19. Geisbert TW, Young HA, Jahrling PB, Davis KJ, Kagan E, et al. (2003) Mechanisms underlying coagulation abnormalities in ebola hemorrhagic fever: overexpression of tissue factor in primate monocytes/macrophages is a key event. J Infect Dis 188: 16181629. [Crossref]

20. Mahanty S, Bray M (2004) Pathogenesis of filoviral haemorrhagic fevers. Lancet Infect Dis 4: 487-498. [Crossref]

21. Shedlock DJ, Aviles J, Talbott KT, Wong G, Wu SJ, et al. (2013) Induction of broad cytotoxic T cells by protective DNA vaccination against Marburg and Ebola. Mol Ther 21: 1432-1444. [Crossref]

22. Koehler JW, Hall AT, Rolfe PA, Honko AN3, Palacios GF4, et al. (2014) Developmen and evaluation of a panel of filovirus sequence capture probes for pathogen detection by next-generation sequencing. PLoS One 9: e107007. [Crossref]

23. Kuhn JH, Becker S, Ebihara H, Geisbert TW, Johnson KM, et al. (2010) Proposal for a revised taxonomy of the family Filoviridae: classification, names of taxa and viruses, and virus abbreviations. Arch Virol 155: 2083-2103. [Crossref]

24. Bradfute SB, Warfield KL, Bavari S (2008) Functional CD8+ T cell responses in lethal Ebola virus infection. J Immunol 180: 4058-4066. [Crossref]

25. Wong G, Qiu X, Olinger GG3, Kobinger GP4 (2014) Post-exposure therapy of filovirus infections. Trends Microbiol 22: 456-463. [Crossref]

26. Reed DS, Lackemeyer MG, Garza NL, Sullivan LJ, Nichols DK (2011) Aerosol exposure to Zaire ebolavirus in three nonhuman primate species: differences in disease course and clinical pathology. Microbes Infect 13: 930-936.

27. Gehring G, Rohrmann K, Atenchong N, Mittler E, Becker S, et al. (2014) The clinically approved drugs amiodarone, dronedarone and verapamil inhibit filovirus cell entry. $J$ Antimicrob Chemother 69: 2123-2131. [Crossref]

28. Basler CF1 (2014) Portrait of a killer: genome of the 2014 EBOV outbreak strain. Cell Host Microbe 16: 419-421. [Crossref]

29. Laupland KB, Valiquette L (2014) Ebola virus disease. Can J Infect Dis Med Microbiol 25: 128-129. [Crossref]

30. Becquart P, Mahlakõiv T, Nkoghe D, Leroy EM1 (2014) Identification of continuous human B-cell epitopes in the VP35, VP40, nucleoprotein and glycoprotein of Ebola virus. PLoS One 9: e96360. [Crossref]

31. McElroy AK, Erickson BR, Flietstra TD, Rollin PE, Nichol ST, et al. (2014) Ebola hemorrhagic Fever: novel biomarker correlates of clinical outcome. J Infect Dis 210: 558-566. [Crossref]

32. Mishra B1 (2014) The threat of Ebola: an update. Indian J Med Microbiol 32: 364-370.

33. Zhang Y, Li D, Jin X, Huang Z (2014) Fighting Ebola with ZMapp: spotlight on plantmade antibody. Sci China Life Sci 57: 987-988. [Crossref]

34. Geisbert TW, Hensley LE (2004) Ebola virus: new insights into disease aetiopathology and possible therapeutic interventions. Expert Rev Mol Med 6: 1-24. [Crossref]

35. Clark DV, Jahrling PB, Lawler JV (2012) Clinical management of filovirus-infected patients. Viruses 4: 1668-1686. [Crossref]

36. Kamata T, Natesan M, Warfield K, Aman MJ, Ulrich RG (2014) Determination of specific antibody responses to the six species of ebola and marburg viruses by multiplexed protein microarrays. Clin Vaccine Immunol 21: 1605-1612. [Crossref]

37. Oestereich L, Lüdtke A, Wurr S, Rieger T, Muñoz-Fontela C, et al. (2014) Successful treatment of advanced Ebola virus infection with T-705 (favipiravir) in a small animal model. Antiviral Res 105: 17-21. [Crossref]

38. Geisbert TW, Young HA, Jahrling PB, Davis KJ, Larsen T, et al. (2003) Pathogenesis 
of Ebola hemorrhagic fever in primate models: evidence that hemorrhage is not a direct effect of virus-induced cytolysis of endothelial cells. Am J Pathol 163: 2371-2382. [Crossref]

39. Bente D, Gren J, Strong JE, Feldmann H (2009) Disease modeling for Ebola and Marburg viruses. Dis Model Mech 2: 12-17. [Crossref]

40. Feldmann H, Volchkov VE, Volchkova VA, Ströher U, Klenk HD (2001) Biosynthesis and role of filoviral glycoproteins. J Gen Virol 82: 2839-2848. [Crossref]

41. Mühlberger E (2007) Filovirus replication and transcription. Future Virol 2: 205-215. [Crossref]

42. Martins KA, Steffens JT, van Tongeren SA, Wells JB, Bergeron AA, et al. (2014) Tolllike receptor agonist augments virus-like particle-mediated protection from Ebola virus with transient immune activation. PLoS One 9: e89735. [Crossref]

43. Mateo M, Carbonnelle C, Martinez MJ, Reynard O, Page A, et al. (2011) Knockdown of Ebola virus VP24 impairs viral nucleocapsid assembly and prevents virus replication. $J$ Infect Dis 204 Suppl 3: S892-896. [Crossref]

44. Nanbo A, Watanabe S, Halfmann P, Kawaoka Y (2013) The spatio-temporal distribution dynamics of Ebola virus proteins and RNA in infected cells. Sci Rep 3: 1206. [Crossref]

45. Radzimanowski J, Effantin G, Weissenhorn W (2014) Conformational plasticity of the Ebola virus matrix protein. Protein Sci 23: 1519-1527. [Crossref]

46. Jasenosky LD, Neumann G, Lukashevich I, Kawaoka Y (2001) Ebola virus VP40induced particle formation and association with the lipid bilayer. J Virol 75: 5205-5214. [Crossref]

47. Kondratowicz AS, Lennemann NJ, Sinn PL, Davey RA, Hunt CL, et al. (2011) T-cell immunoglobulin and mucin domain 1 (TIM-1) is a receptor for Zaire Ebolavirus and Lake Victoria Marburgvirus. Proc Natl Acad Sci U S A 108: 8426-8431. [Crossref]

48. Takada A, Robison C, Goto H, Sanchez A, Murti KG, et al. (1997) A system for functional analysis of Ebola virus glycoprotein. Proc Natl Acad Sci U S A 94: 14764 14769. [Crossref]

49. Carette JE, Raaben M, Wong AC, Herbert AS, Obernosterer G, et al. (2011) Ebola virus entry requires the cholesterol transporter Niemann-Pick C1. Nature 477: 340343. [Crossref]

50. Miller EH, Obernosterer G, Raaben M, Herbert AS, Deffieu MS, et al (2012) Ebola virus entry requires the host-programmed recognition of an intracellular receptor. EMBO J 31: 1947-1960. [Crossref]

51. Kaletsky RL, Francica JR, Agrawal-Gamse C, Bates P (2009) Tetherin-mediated restriction of filovirus budding is antagonized by the Ebola glycoprotein. Proc Natl Acad Sci U S A 106: 2886-2891. [Crossref]

52. Kuhl AC, Banning A, Marzi J, Votteler I, Steffen S, et al. (2011) The Ebola virus glycoprotein and HIV-1 Vpu employ different strategies to counteract the antiviral factor tetherin. J Infect Dis 3: S850-860. [Crossref]

53. Neil SJ, Zang T, Bieniasz PD (2008) Tetherin inhibits retrovirus release and is antagonized by HIV-1 Vpu. Nature 451: 425-430. [Crossref]

54. Bray M, Geisbert TW (2005) Ebola virus: the role of macrophages and dendritic cells in the pathogenesis of Ebola hemorrhagic fever. Int J Biochem Cell Biol 37: 1560-1566. [Crossref]

55. Bosio CM, Aman MJ, Grogan C, Hogan R, Ruthel G, et al. (2003) Ebola and Marburg viruses replicate in monocyte-derived dendritic cells without inducing the production of cytokines and full maturation. J Infect Dis 188: 1630-1638. [Crossref]

56. Mahanty S, Hutchinson K, Agarwal S, McRae M, Rollin PE, et al. (2003) Cutting edge: impairment of dendritic cells and adaptive immunity by Ebola and Lassa viruses. $J$ Immunol 170: 2797-2801. [Crossref]

57. Hoenen T, Feldmann H (2014) Reverse genetics systems as tools for the development of novel therapies against filoviruses. Expert Rev Anti Infect Ther 12: 1253-1263. [Crossref]

58. Cárdenas WB, Loo YM, Gale M Jr, Hartman AL, Kimberlin CR, et al. (2006) Ebola virus VP35 protein binds double-stranded RNA and inhibits alpha/beta interferon production induced by RIG-I signaling. J Virol 80: 5168-5178. [Crossref]

59. Luthra P, Ramanan P, Mire CE, Weisend C, Tsuda Y, et al. (2013) Mutual antagonism between the Ebola virus VP35 protein and the RIG-I activator PACT determines infection outcome. Cell Host Microbe 14: 74-84. [Crossref]

60. Jin H, Yan Z, Prabhakar BS, Feng Z, Ma Y, et al. (2010) The VP35 protein of Ebola virus impairs dendritic cell maturation induced by virus and lipopolysaccharide. $J$ Gen Virol 91: 352-361. [Crossref]

61. Lubaki NM, Ilinykh P, Pietzsch C, Tigabu B, Freiberg AN, et al. (2013) The lack of maturation of Ebola virus-infected dendritic cells results from the cooperative effect of at least two viral domains. J Virol 87: 7471-7485. [Crossref]

62. Bale S, Julien JP, Bornholdt ZA, Krois AS, Wilson IA, et al. (2013) Ebolavirus VP35 coats the backbone of double-stranded RNA for interferon antagonism. $J$ Virol 87: 10385-10388. [Crossref]

63. Haasnoot J, de Vries W, Geutjes EJ, Prins M, de Haan P, et al. (2007) The Ebola virus VP35 protein is a suppressor of RNA silencing. PLoS Pathog 3: e86. [Crossref]

64. Gire SK, Goba A, Andersen KG, Sealfon RS, Park DJ, et al. (2014) Genomic surveillance elucidates Ebola virus origin and transmission during the 2014 outbreak. Science 345: 1369-1372. [Crossref]

65. Bühler S, Roddy P, Nolte E, Borchert M (2014) Clinical documentation and data transfer from Ebola and Marburg virus disease wards in outbreak settings: health care workers' experiences and preferences. Viruses 6: 927-937.

66. Forrester JD, Hunter JC, Pillai SK, Arwady MA, Ayscue P, et al. (2014) Cluster of ebola cases among liberian and u.s. Health care workers in an ebola treatment unit and adjacent hospital - liberia, 2014. MMWR Morb Mortal Wkly Rep 63: 925-929.

67. Gulland A (2014) WHO hopes Ebola incidence will decline after peaking in December. BMJ 349: g6255. [Crossref]

68. Martines RB, Ng DL, Greer PW, Rollin PE, Zaki SR (2015) Tissue and cellular tropism, pathology and pathogenesis of Ebola and Marburg viruses. J Pathol 235: 153 174. [Crossref]

69. Garrison AR, Giomarelli BG, Lear-Rooney CM, Saucedo CJ, Yellayi S, et al. (2014) The cyanobacterial lectin scytovirin displays potent in vitro and in vivo activity against Zaire Ebola virus. Antiviral Res 112: 1-7. [Crossref]

70. Shuchman M (2014) Could interferon help treat Ebola? CMAJ 186: 1204. [Crossref]

71. Polonsky JA, Wamala JF, de Clerck H, Van Herp M, Sprecher A, et al. (2014) Emerging filoviral disease in Uganda: proposed explanations and research directions. Am J Trop Med Hyg 90: 790-793. [Crossref]

72. Fitzpatrick G, Vogt F, Moi Gbabai O, Black B, Santantonio M, et al. (2014) Describing readmissions to an Ebola case management centre (CMC), Sierra Leone, 2014. Euro Surveill 19: 20924. [Crossref]

73. Chippaux JP1 (2014) Outbreaks of Ebola virus disease in Africa: the beginnings of a tragic saga. J Venom Anim Toxins Incl Trop Dis 20: 44. [Crossref]

74. Gulland A1 (2014) Fifteen countries are at risk of Ebola outbreak, says WHO. BMJ 349: g6305. [Crossref]

75. Fasina FO, Shittu A, Lazarus D, Tomori O, Simonsen L, et al. (2014) Transmission dynamics and control of Ebola virus disease outbreak in Nigeria, July to September 2014. Euro Surveill 19: 20920. [Crossref]

76. Liang H, Zhou Z, Zhang S, Zen K, Chen X, et al. (2014) Identification of Ebola virus microRNAs and their putative pathological function. Sci China Life Sci 57: 973-981. [Crossref]

77. Isakov A, Jamison A, Miles W, Ribner B (2014) Safe management of patients with serious communicable diseases: recent experience with Ebola virus. Ann Intern Med 161: 829-830. [Crossref]

78. Lippi G, Mattiuzzi C, Plebani M (2014) Laboratory preparedness to face infectious outbreaks. Ebola and beyond. Clin Chem Lab Med 52: 1681-1684. [Crossref]

79. Watt A, Moukambi F, Banadyga L, Groseth A, Callison J, et al. (2014) A novel life cycle modeling system for Ebola virus shows a genome length-dependent role of VP24 in virus infectivity. $J$ Virol 88: 10511-10524. [Crossref]

80. Hoenen T, Watt A, Mora A, Feldmann H (2014) Modeling the lifecycle of Ebola virus under biosafety level 2 conditions with virus-like particles containing tetracistronic minigenomes. J Vis Exp: 52381. [Crossref]

81. Kucharski AJ, Edmunds WJ2 (2014) Case fatality rate for Ebola virus disease in west Africa. Lancet 384: 1260. [Crossref]

82. Peters CJ, Liu CT, Anderson GW Jr, Morrill JC, Jahrling PB (1989) Pathogenesis of viral hemorrhagic fevers: Rift Valley fever and Lassa fever contrasted. Rev Infect Dis 11 Suppl 4: S743-749. [Crossref]

83. Maganga GD, Kapetshi J, Berthet N, Kebela Ilunga B, Kabange F, et al. (2014) Ebola 
virus disease in the Democratic Republic of Congo. N Engl J Med 371: 2083-2091. [Crossref]

84. Laupland KB, Valiquette L2 (2014) Ebola virus disease. Can J Infect Dis Med Microbiol 25: 128-129. [Crossref]

85. Baize S, Leroy EM, Georges-Courbot MC, Capron M, Lansoud-Soukate J, et al. (1999) Defective humoral responses and extensive intravascular apoptosis are associated with fatal outcome in Ebola virus-infected patients. Nat Med 5: 423-426. [Crossref]

86. Michelow IC, Lear C, Scully C, Prugar LI, Longley CB, et al. (2011) High-dose mannose-binding lectin therapy for Ebola virus infection. J Infect Dis 203: 175-179. [Crossref]

87. Larsen T, Stevens EL, Davis KJ, Geisbert JB, Daddario-DiCaprio KM, et al. (2007) Pathologic findings associated with delayed death in nonhuman primates experimentally infected with Zaire Ebola virus. J Infect Dis 196: S323-S328. [Crossref]

88. Ebihara H, Zivcec M, Gardner D, Falzarano D, LaCasse R, et al. (2013) A Syrian golden hamster model recapitulating ebola hemorrhagic fever. J Infect Dis 207: 306318. [Crossref]

89. Nkoghe D, Leroy EM, Toung-Mve M, Gonzalez JP (2012) Cutaneous manifestations of filovirus infections. Int J Dermatol 51: 1037-1043. [Crossref]

90. Nolte KB, Hanzlick RL, Payne DC, Kroger AT, Oliver WR, et al. (2004) Medical examiners, coroners, and biologic terrorism: a guidebook for surveillance and case management. MMWR Recomm Rep 53: 1-27. [Crossref]

91. Chertow DS, Kleine C, Edwards JK, Scaini R, Giuliani R, et al. (2014) Ebola virus disease in West Africa--clinical manifestations and management. $N$ Engl J Med 371: 2054-2057. [Crossref]
92. (1985) Viral haemorrhagic fevers. Report of a WHO Expert Committee. World Health Organ Tech Rep Ser 721: 5-126. [Crossref]

93. Hantel A, Olopade CO (2015) Drug and vaccine access in the ebola epidemic: advising caution in compassionate use. Ann Intern Med 162: 141-142. [Crossref]

94. Yusuf I, Adam RU, Ahmad SA, Yee PL (2014) Ebola and compliance with infection prevention measures in Nigeria. Lancet Infect Dis 14: 1045-1046. [Crossref]

95. Folayan M, Brown B, Yakubu A, Peterson K, Haire B (2014) Compassionate use of experimental drugs in the Ebola outbreak. Lancet 384: 1843-1844. [Crossref]

96. Hasle G (2014) New rules needed to stop the Ebola epidemic. Tidsskr Nor Laegeforen 134: 1826-1827. [Crossref]

97. Joffe S (2014) Evaluating novel therapies during the Ebola epidemic. JAMA 312: 12991300. [Crossref]

98. Griffiths PD (2014) Ebola and ethics. Rev Med Virol 24: 363-364. [Crossref]

99. Soni SP, Stahelin RV (2014) The Ebola virus matrix protein VP40 selectively induces vesiculation from phosphatidylserine-enriched membranes. J Biol Chem 289: 33590 33597. [Crossref]

100. Richardson-Boedler C (1999) Sicarius (six-eyed crab spider): a homeopathic treatment for Ebola haemorrhagic fever and disseminated intravascular coagulation? Br Homeopath J 88: 24-27. [Crossref]

101. Steele KE, Stabler K, Vander Zanden L (2001) Cutaneous DNA vaccination against Ebola virus by particle bombardment: histopathology and alteration of CD3-positive dendritic epidermal cells. Vet Pathol 38: 203-215. [Crossref]

102. Kanapathipillai R, Henao Restrepo AM, Fast P, Wood D, Dye C, et al. (2014) Ebola vaccine--an urgent international priority. $N$ Engl J Med 371: 2249-2251. [Crossref]

Copyright: (C2015 Nooshin Bagherani. This is an open-access article distributed under the terms of the Creative Commons Attribution License, which permits unrestricted use, distribution, and reproduction in any medium, provided the original author and source are credited. 